\title{
Effects of mulberry ethanol extracts on hydrogen peroxide-induced oxidative stress in pancreatic $\beta$-cells
}

\author{
YOUNG RAE KIM ${ }^{1}$, JONG SEOK LEE ${ }^{1}$, KI RIM LEE ${ }^{1}$, YOUNG EON KIM ${ }^{2}$, \\ NAM IN BAEK ${ }^{3}$ and EOCK KEE HONG ${ }^{1}$
}

\author{
${ }^{1}$ Department of Bioengineering and Technology, Kangwon National University, Chuncheon, Kangwon-do 200-701; \\ ${ }^{2}$ Korea Food Research Institute, Songnam-si, Kyunggi-do 463-746; ${ }^{3}$ Department of Oriental Medicinal Materials \\ and Processing, Kyung Hee University, Yongin-si, Gyeonggi-do 446-701, Republic of Korea
}

Received July 10, 2013; Accepted October 1, 2013

DOI: 10.3892/ijmm.2013.1534

\begin{abstract}
Reactive oxygen species (ROS) are key mediators of mammalian cellular damage and are associated with diseases such as aging, arteriosclerosis, inflammation, rheumatoid arthritis and diabetes. Type 1 diabetes develops upon the destruction of pancreatic $\beta$-cells, which is partly due to ROS activity. In this study, we investigated the cytoprotective and anti-oxidative effects of fractionated mulberry extracts in mouse insulin-producing pancreatic $\beta$-cells (MIN6N cells). Treatment with hydrogen peroxide $\left(\mathrm{H}_{2} \mathrm{O}_{2}\right)$ induced significant cell death and increased intracellular ROS levels, lipid peroxidation and DNA fragmentation in the MIN6N cells. Fractionated mulberry extracts significantly reduced the $\mathrm{H}_{2} \mathrm{O}_{2}$-dependent production of intracellular ROS, 2,2-diphenyl-1-picrylhydrazyl (DPPH) radicals and lipid peroxidation. In addition, mulberry extracts inhibited DNA fragmentation induced by $\mathrm{H}_{2} \mathrm{O}_{2}$. Thus, the antioxidant properties of mulberry extracts in pancreatic $\beta$-cells may be exploited for the prevention or treatment of type 1 diabetes.
\end{abstract}

\section{Introduction}

Reactive oxygen species (ROS) are derived from the metabolism of molecular oxygen and chemically reactive molecules containing oxygen, such as superoxide anion radicals $\left(\mathrm{O}_{2}^{-}\right)$, hydrogen peroxide $\left(\mathrm{H}_{2} \mathrm{O}_{2}\right)$ and hydroxyl radicals $(-\mathrm{OH})$. Under normal cellular conditions, ROS are primarily generated by mitochondrial respiratory metabolism and are then efficiently neutralized by cellular antioxidant defense mechanisms such as superoxide dismutase (SOD), catalase (CAT) and glutathione peroxidase (GPx) (1-3). However, the excessive generation of

Correspondence to: Professor Eock Kee Hong, Department of Bioengineering and Technology, College of Engineering, Kangwon National University, 192-1 Hyoja-2-dong, Chuncheon, Kangwon-do 200-701, Republic of Korea

E-mail: ekhong@kangwon.ac.kr

Key words: MIN6N cells, diabetes, oxidative stress, mulberry, Morus, pancreas
ROS during environmental stress results in significant oxidative damage to lipids, DNA and proteins (4). Such ROS-dependent damage can lead to dysfunction or cell death. Consequently, ROS have been implicated in the aging process, carcinogenesis, rheumatoid arthritis and inflammation (5). Excessive ROS are particularly deleterious in the pancreas, and their levels correlate with the loss of $\beta$-cell mass, islet destruction and dysfunction in diabetes (6).

Diabetes is a group of metabolic diseases in which a person has high blood sugar caused either by defective insulin production, insufficient insulin activity or both (7). Among the subtypes, type 1 diabetes is due to an absolute deficiency of insulin secretion resulting from the loss of $\beta$-cells upon autoimmune attack or oxidative stress (8). The major effects of insulin include the promotion of glucose uptake, the stimulation of glycogen synthesis in the liver and muscle, triglyceride formation and storage in adipocytes and an increase in protein synthesis $(9,10)$. Insufficient insulin secretion and its downstream consequences thus lead to high blood sugar levels. Prolonged insulin dysfunction results in the progressive development of specific complications, including retinopathy with potential blindness, nephropathy that may lead to renal failure, neuropathy with risk of foot ulcers, limb amputation and cardiovascular disease (11). In modern medicine, there are no effective curative therapies for diabetes mellitus (12). In addition, current anti-diabetic therapies, such as insulin injection and hypoglycemic agents, usually have adverse sideeffects and decreased efficacy over time $(13,14)$. They can also be relatively ineffective against certain long-term diabetic complications and are associated with a high cost for patients and the health care industry $(15,16)$. Therefore, the development of anti-diabetic natural products would be a promising solution for patients confronted with the negative side-effects of current anti-diabetic therapies (17).

In traditional medicine, several medicinal plants or their extracts are widely used in a number of countries for the treatment of disease. Morus alba (M. alba), the mulberry plant, belongs to this class of well-known natural medicinal species. M. alba belongs to the family Moraceae and the genus Morus and is a perennial, fast-growing woody plant that has a short proliferation period (18). Usually, 10-16 species of the genus Morus are found in subtropical, warm and temperate regions 
of Asia, Africa and North America. The roots and leaves of $M$. alba are used in Chinese traditional medicine for their various health benefits and for treating ailments. In recent studies, the antioxidant activity of parts of the plant, such as the roots and leaves in different model systems have also been documented (19-22). However, the potential effects of mulberry extracts, (the actual fruit of M.alba), in the treatment of diabetes are currently unclear.

To this end, in this study, we aimed to assess the effects of mulberry extracts on $\mathrm{H}_{2} \mathrm{O}_{2}$-induced oxidative injury in insulinproducing pancreatic MIN6N $\beta$-cells and to determine whether the extracts may be used in the treatment of type 1 diabetes.

\section{Materials and methods}

Materials. Dulbecco's modified Eagle's medium (DMEM), fetal bovine serum (FBS), penicillin-streptomycin (PS) and trypsin-EDTA were purchased from Gibco (Grand Island, NY, USA). 2',7'-Dichlorodihydrofluorescein diacetate ( $\left.\mathrm{H}_{2} \mathrm{DCF}-\mathrm{DA}\right)$ was obtained from Molecular Probes (Carlsbad, CA, USA). 2,2-Diphenyl-1-picrylhydrazyl (DPPH), $\mathrm{H}_{2} \mathrm{O}_{2}$ and Hoechst 33342 were purchased from Sigma Biochemical (St. Louis, MO, USA). All other chemicals were of analytical grade.

Preparation of fractionated extracts. An ethanol extract of the mulberry fruits $(15 \mathrm{~kg}$ ) was acquired by extraction with $70 \%$ ethanol (36 liters) for $24 \mathrm{~h}$ at room temperature 3 times. The solvent was filtered and evaporated under a vacuum to afford 2,200 g crude ethanol extracts (yield, 14.6\%). The lyophilized crude ethanol extracts were successively fractionated with ethyl-acetate (EtOAc, MAE extract), n-butanol (BuOH, MAB extract) and water $\left(\mathrm{H}_{2} \mathrm{O}, \mathrm{MAH}\right.$ extract). Each fraction was evaporated in vacuo. The yields of the extracts and the fractions were as follows: $1.59 \%$ (EtOAc fraction), $10.23 \%(\mathrm{BuOH}$ fraction) and $83.63 \%\left(\mathrm{H}_{2} \mathrm{O}\right.$ fraction).

Cell culture. Mouse insulin-producing MIN6N pancreatic $\beta$-cells were derived from a mouse pancreatic islet cell line. The MIN6N $\beta$-cells were provided by Professor H.Y. Kwon (College of Medicine, Hallym University, Chuncheon, Korea). The cells were cultured in DMEM (11 mM glucose; Gibco) supplemented with $10 \%$ inactivated FBS and $1 \%$ PS and maintained at $37^{\circ} \mathrm{C}$ in a humidified $5 \% \mathrm{CO}_{2}$ incubator. The cells were cultured up to approximately $85 \%$ confluence and harvested with $0.25 \%$ trypsin-EDTA. The cells were harvested and subcultured for an additional $48 \mathrm{~h}$ in DMEM. The cells were maintained in these culture conditions for all the experiments.

DPPH radical scavenging activity. The effects of the fractionated extracts (MAB, MAE and MAH) on DPPH radicals was estimated according to the Blois method (1). MAB, MAE and $\mathrm{MAH}$ were dissolved in EtOH over a concentration range of 10 to $500 \mu \mathrm{g} / \mathrm{ml}$. Each sample solution (400 $\mu \mathrm{l}$ each) was mixed with DPPH solution $(600 \mu \mathrm{l})$ and incubated for $30 \mathrm{~min}$. to allow reactions. The absorbance of the resulting solution was measured at $520 \mathrm{~nm}$ using an ELISA microplate reader (Model 550; Bio-Rad Laboratories, Inc., Hercules, CA, USA).

Measurement of cytotoxicity. The cytotoxic effects of the fractionated extracts in pancreatic MIN6N $\beta$-cells were evaluated using the 3-(4,5-dimethylthiazol-2-yl)-2,5-diphenyltetrazolium bromide (MTT) assay, which is based on the reduction of a tetrazolium salt by mitochondrial dehydrogenase in viable cells (23). The MIN6N $\beta$-cells were seeded in 12-well plates and incubated for $24 \mathrm{~h}$. The cells were then treated with the fractionated extracts and incubated for $20 \mathrm{~h}$ at $37^{\circ} \mathrm{C} ; 500 \mu \mathrm{g} / \mathrm{ml}$ MTT working solution were then added to each well followed by incubation for $2.5 \mathrm{~h}$ at $37^{\circ} \mathrm{C}$. The violet formazan crystal in each well was dissolved in isopropyl alcohol and the absorbance of each well was measured at $570 \mathrm{~nm}$ using an ELISA microplate reader (model 550; Bio-Rad Laboratories, Inc.).

Analysis of the protective effects of mulberry extracts. To investigate the protective effects of the fractionated extracts against $\mathrm{H}_{2} \mathrm{O}_{2}$-induced cell death, the cells were first incubated with DMEM containing $0.5 \%$ FBS for $24 \mathrm{~h}$. Following this, the indicated dose of the fractionated extract was added for $20 \mathrm{~h}$, prior to treatment with $0.7 \mathrm{mM} \mathrm{H}_{2} \mathrm{O}_{2}$ for $4 \mathrm{~h}$. Cell viability was measured by MTT assay. In brief, $500 \mu \mathrm{g} / \mathrm{ml}$ MTT solution were added to each well followed by incubation for $2.5 \mathrm{~h}$ at $37^{\circ} \mathrm{C}$. The absorbance of each well was then measured at $570 \mathrm{~nm}$ using an ELISA microplate reader (model 550; Bio-Rad Laboratories, Inc.).

Intracellular ROS scavenging activity and image analysis. To determine the effects of fractionated extracts on $\mathrm{H}_{2} \mathrm{O}_{2}$-induced intracellular ROS generation, the MIN6N $\beta$-cells were seeded in 12-well plates the day prior to treatment with the extracts. The $\beta$-cells were treated with various concentrations of fractionated extracts for $20 \mathrm{~h}$, followed by the addition of $0.7 \mathrm{mM}$ $\mathrm{H}_{2} \mathrm{O}_{2}$ to each well. After $4 \mathrm{~h}$ of incubation, $5 \mu \mathrm{M} \mathrm{H}_{2} \mathrm{DCF}-\mathrm{DA}$ solution in phosphate-buffered saline (PBS, $\mathrm{pH}$ 7.38) was added and the fluorescence was measured at excitation and emission wavelengths of 485 and $535 \mathrm{~nm}$, respectively, using a microplate spectrofluorometer. For image analysis of the production of intracellular ROS, the MIN6N $\beta$-cells were seeded in cover slip-loaded 12 -well plates, which were then treated with various concentrations of fractionated extracts for $20 \mathrm{~h}$, followed by the addition of $0.7 \mathrm{mM} \mathrm{H}_{2} \mathrm{O}_{2}$ to each well. After $4 \mathrm{~h}$ of incubation, $\mathrm{H}_{2} \mathrm{DCF}-\mathrm{DA}$ solution was added to each well of the plate, which was incubated for $2 \mathrm{~h}$ at $37^{\circ} \mathrm{C}$. Images of the stained cells were collected using a fluorescence microscope (Nikon, Tokyo, Japan).

Lipid peroxidation inhibitory activity. Lipid peroxidation was assayed using the thiobarbituric acid (TBA) reaction as previously described (24). In brief, the cells were seeded in 12-well plates and incubated for $24 \mathrm{~h}$. Subsequently, the cells were treated with various concentrations of fractionated extracts for $20 \mathrm{~h}$, followed by the addition of $0.7 \mathrm{mM} \mathrm{H}_{2} \mathrm{O}_{2}$ to each well. After $4 \mathrm{~h}$ of incubation, the cells were washed with cold PBS, harvested with $0.25 \%$ trypsin-EDTA and homogenized in cold $1.15 \%$ potassium chloride $(\mathrm{KCl})$. A $100-\mathrm{ml}$ aliquot of homogenized cells was then mixed with $0.2 \mathrm{ml}$ of $8.1 \%$ sodium dodecyl sulfate, $1.5 \mathrm{ml}$ of $20 \%$ acetic acid ( $\mathrm{pH} \mathrm{3.6)}$ and $1.5 \mathrm{ml}$ of $0.8 \%$ TBA. The solution was then heated to $95^{\circ} \mathrm{C}$ for $2 \mathrm{~h}$. After cooling at room temperature, an $\mathrm{BuOH} /$ pyridine mixture $(15: 1, \mathrm{v} / \mathrm{v})$ was added and the mixture was shaken for $5 \mathrm{~min}$ and then centrifuged at $1,000 \mathrm{x} \mathrm{g}$ for $10 \mathrm{~min}$. The supernatant was isolated and the absorbance was measured at $535 \mathrm{~nm}$. 


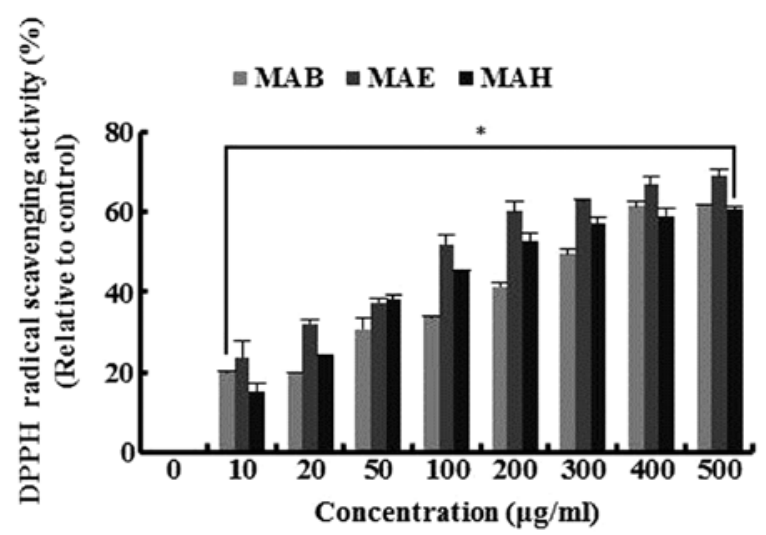

Figure 1. 2,2-Diphenyl-1-picrylhydrazyl (DPPH) radical scavenging activity of fractionated extracts. The amount of DPPH radicals was determined spectrophotometrically at $520 \mathrm{~nm}$ following incubation with the extracts over a range of concentrations $(0-500 \mu \mathrm{g} / \mathrm{ml})$. Data represent the means \pm SE of 3 independent experiments. " $\mathrm{p}<0.05$, significant difference compared with the non-treated group, as shown by the Student's t-test. MAB, ethyl-acetate extract; MAB, n-butanol extract; MAH, water extract.

Image analysis of DNA fragmentation. The MIN6N $\beta$-cells were labeled using the cell-permeable, DNA-specific fluorescent dye, Hoechst 33342 as previously described (25). Cells with homogeneously stained nuclei were considered viable, whereas the presence of chromatin fragmentation was indicative of $\mathrm{H}_{2} \mathrm{O}_{2}$-induced apoptosis (26). The MIN6N $\beta$-cells were seeded in 12-well plates. Twenty-four hours later, the cells were treated with various concentrations of fractionated extracts for $20 \mathrm{~h}$, followed by further incubation for $4 \mathrm{~h}$ prior to exposure to $0.7 \mathrm{mM} \mathrm{H}_{2} \mathrm{O}_{2}$. Hoechst 33342 working solution was then added to each well, followed by $15 \mathrm{~min}$ of incubation at room temperature. Images of the stained cells were collected using a fluorescence microscope (Nikon), in order to examine the degree of DNA fragmentation.
Statistical analysis. All measurements are from at least 3 independent experiments and the values are expressed as the means \pm SD. Statistical analysis was performed using the Student's t-test. A value of $p<0.05$ was considered to indicate a statistically significant difference.

\section{Results}

DPPH radical scavenging activity of fractionated extracts. To determine the radical scavenging activity of the fractionated extracts, we measured scavenged DPPH radicals in the presence or absence of fractionated extracts (MAB, MAE and MAH). As shown Fig. 1, the extracts scavenged the DPPH radicals in a dose-dependent manner, with a $400 \mu \mathrm{g} / \mathrm{ml}$ dose of each extract inducing a reduction in DPPH radicals between 59 and $67 \%$. MAE exhibited the most potent DPPH radical scavenger activity, inducing reductions of 51,67 and 69\% at concentrations of 100,400 and $500 \mu \mathrm{g} / \mathrm{ml}$, respectively. These results suggest that fractionated mulberry fruit extracts have good antioxidant properties.

Cytotoxicity of fractionated extracts of mulberry in pancreatic $\beta$-cells. To determine the range of doses over which fractionated extracts of mulberry were non-toxic, MIN6N $\beta$-cell viability was measured by MTT assay (Fig. 2). Cell viability was $>90 \%$ in the presence of all extracts, up to a concentration of $200 \mu \mathrm{g} / \mathrm{ml}$ and in the case of MAE, viability was still above this value (92\%) at a $400 \mu \mathrm{g} / \mathrm{ml}$ dose.

Cytotoxicity of $\mathrm{H}_{2} \mathrm{O}_{2}$ in the MIN6N $\beta$-cells. To measure the cytotoxicity of $\mathrm{H}_{2} \mathrm{O}_{2}$, we treated the cells with various doses of $\mathrm{H}_{2} \mathrm{O}_{2}$ for $4 \mathrm{~h}$. As shown in Fig. 3A, the concentrations of $\mathrm{H}_{2} \mathrm{O}_{2}$ at $\geq 0.7 \mathrm{mM}$ markedly reduced cell viability, with cell death reaching approximately $57 \%$ at $0.7 \mathrm{mM} \mathrm{H}_{2} \mathrm{O}_{2}$. This dose of $\mathrm{H}_{2} \mathrm{O}_{2}$ also induced cell death in a time-dependent manner (Fig. 3B). We thus selected $0.7 \mathrm{mM} \mathrm{H}_{2} \mathrm{O}_{2}$ and an exposure time of $4 \mathrm{~h}$ for the subsequent experiments.

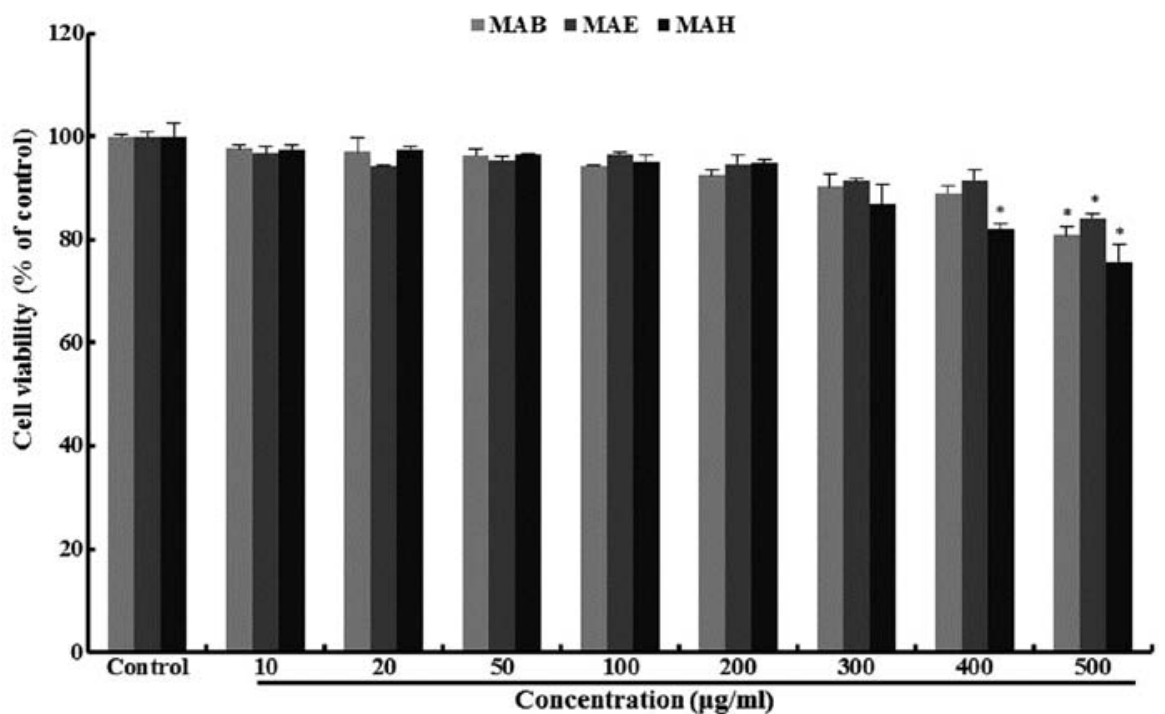

Figure 2. Cell viability of mouse insulin-producing pancreatic $\beta$-cells (MIN6N cells) treated with various concentrations of fractionated extracts. To determine the maximum non-toxic concentration of the fractionated extracts, confluent cells were treated with various concentrations $(10-500 \mu \mathrm{g} / \mathrm{ml})$ of extracts for $24 \mathrm{~h}$. Cell viability was determined by MTT assay. Data represent the means \pm SE of 3 independent experiments. ${ }^{*} p<0.05$, significant difference compared with the control, as shown by the Student's t-test. MAB, ethyl-acetate extract; MAB, n-butanol extract; MAH, water extract. 

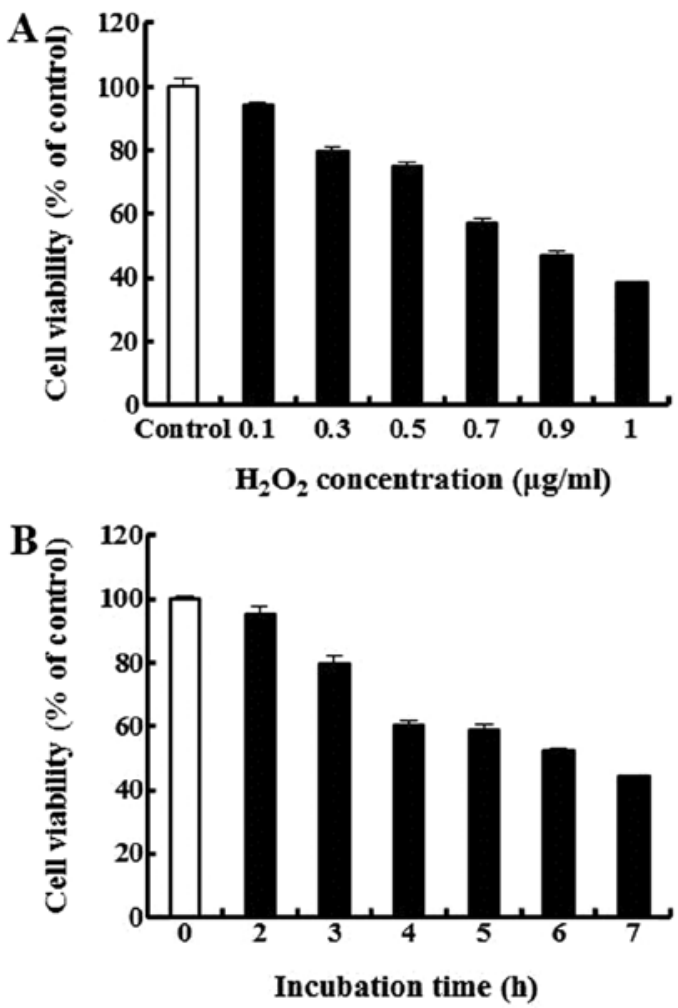

Figure 3. Cell viability of mouse insulin-producing pancreatic $\beta$-cells (MIN6N cells) exposed to $\mathrm{H}_{2} \mathrm{O}_{2}$. The determination of the cytotoxicity of $\mathrm{H}_{2} \mathrm{O}_{2}$ was examined following (A) exposure to various concentration of $\mathrm{H}_{2} \mathrm{O}_{2}$ for $4 \mathrm{~h}$ or (B) exposure to a fixed $0.7 \mathrm{mM}$ dose of $\mathrm{H}_{2} \mathrm{O}_{2}$ for different periods of time. The viability of the cells damaged by $\mathrm{H}_{2} \mathrm{O}_{2}$ was determined by MTT assay. Data represent the means \pm SE of 3 independent experiments. "p $<0.05$, significant difference compared with the control, as shown by the Student's t-test.

Protective effects of fractionated mulberry extracts in MIN6N $\beta$-cells. The protective effects of MAB, MAE and MAH in the $\mathrm{H}_{2} \mathrm{O}_{2}$-treated MIN6N $\beta$-cells were measured by MTT assay. The cells were pre-treated with various concentrations of MAB, MAE and MAH for $20 \mathrm{~h}$, followed by treatment with $\mathrm{H}_{2} \mathrm{O}_{2}$ for $4 \mathrm{~h}$. In these experiments, cell viability decreased to approximately $55 \%$ following treatment with $\mathrm{H}_{2} \mathrm{O}_{2}$ in the controls. Pre-treatment with $100 \mu \mathrm{g} / \mathrm{ml}$ MAB, MAE and MAH restored cell viability to 62,75 and $63 \%$ of the control (Fig. 4), respectively. MAE was particularly effective in preventing $\mathrm{H}_{2} \mathrm{O}_{2}$-induced cell death. Thus, we conclude that all 3 extracts are capable of preventing cell death induced by oxidative stress.

Intracellular ROS scavenging activity of fractionated mulberry extracts. Intracellular ROS levels in the $\mathrm{H}_{2} \mathrm{O}_{2}$-treated MIN6N $\beta$-cells were determined using the ROS-sensitive fluorescent probe, $\mathrm{H}_{2}$ DCF-DA, which is cleaved by intracellular esterases into its non-fluorescent form, DCFH. This form, which is no longer membrane permeable, can be further oxidized by $\mathrm{H}_{2} \mathrm{O}_{2}$ to its fluorescent form, DCF (27). MAB, MAE and MAH were able to scavenge intracellular ROS in a dose-dependent manner. Consistent with its protective effects on cell viability, MAE was a much more effective suppressor of intracellular ROS compared with the other fractions. The ROS scavenging activity increased up to approximately $34 \%$ with $100 \mu \mathrm{g} / \mathrm{ml}$ MAE compared with the cells treated only with $\mathrm{H}_{2} \mathrm{O}_{2}$ (Fig. 5A).
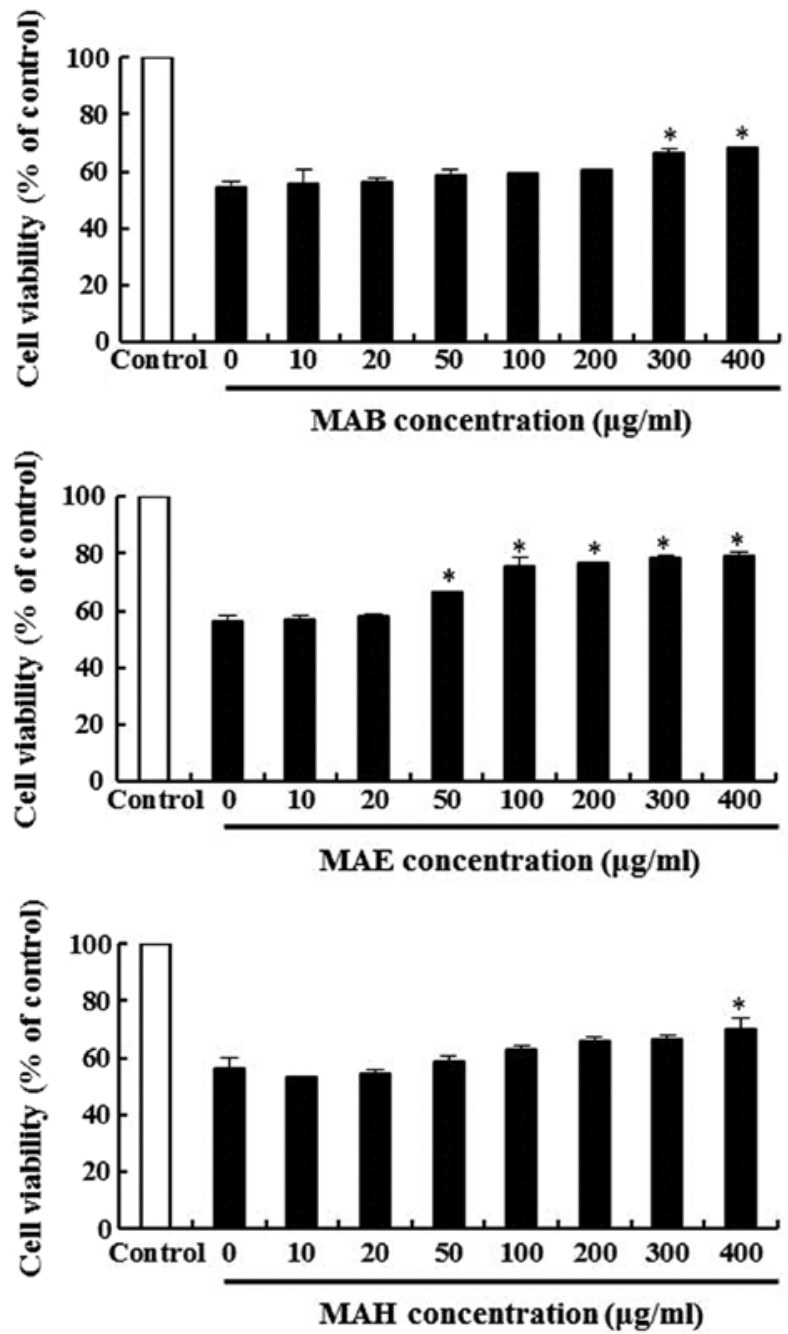

Figure 4. Protective effects of fractionated extracts against oxidative stressdamaged mouse insulin-producing pancreatic $\beta$-cells (MIN6N cells). MIN6N $\beta$-cells were treated with various concentrations of fractionated extracts $(10-400 \mu \mathrm{g} / \mathrm{ml})$ for $20 \mathrm{~h}$ and $0.7 \mathrm{mM} \mathrm{H}_{2} \mathrm{O}_{2}$ was then added for $4 \mathrm{~h}$. Cell viability was determined by MTT assay. Data represent the means $\pm \mathrm{SE}$ of 3 independent experiments. ${ }^{*} \mathrm{p}<0.05$, significant difference compared with the $\mathrm{H}_{2} \mathrm{O}_{2}$-treated group, as shown by the Student's t-test. MAB, ethyl-acetate extract; MAB, n-butanol extract; MAH, water extract.

In the fluorescent microscopic images, the fluorescence intensity of the $\mathrm{H}_{2}$ DCF-DA stain was enhanced in the $\mathrm{H}_{2} \mathrm{O}_{2}$ treated MIN6N $\beta$-cells. As a result, the fractionated mulberry extracts reduced the green fluorescence intensity, compared with the cells treated only with $\mathrm{H}_{2} \mathrm{O}_{2}$, indicating a reduction in ROS generation. Among the fractionated extracts, MAB and MAE markedly decreased the intracellular fluorescence intensity at $100 \mu \mathrm{g} / \mathrm{ml}$ (Fig. 5B). These data suggest that MAB and MAE possessed greater ROS scavenging activity than MAH.

Inhibitory effect of fractionated mulberry extracts on lipid peroxidation in MIN6N $\beta$-cells. Based on the above results, we hypothesized that the antioxidant properties of the extracts would reduce ROS-induced cellular damage, such as lipid peroxidation and DNA fragmentation.

The inhibitory effect of the fractionated extracts on lipid peroxidation in $\mathrm{H}_{2} \mathrm{O}_{2}$-treated MIN6N $\beta$-cells was determined by measuring TBA reactive substances (TBARS), lipid 

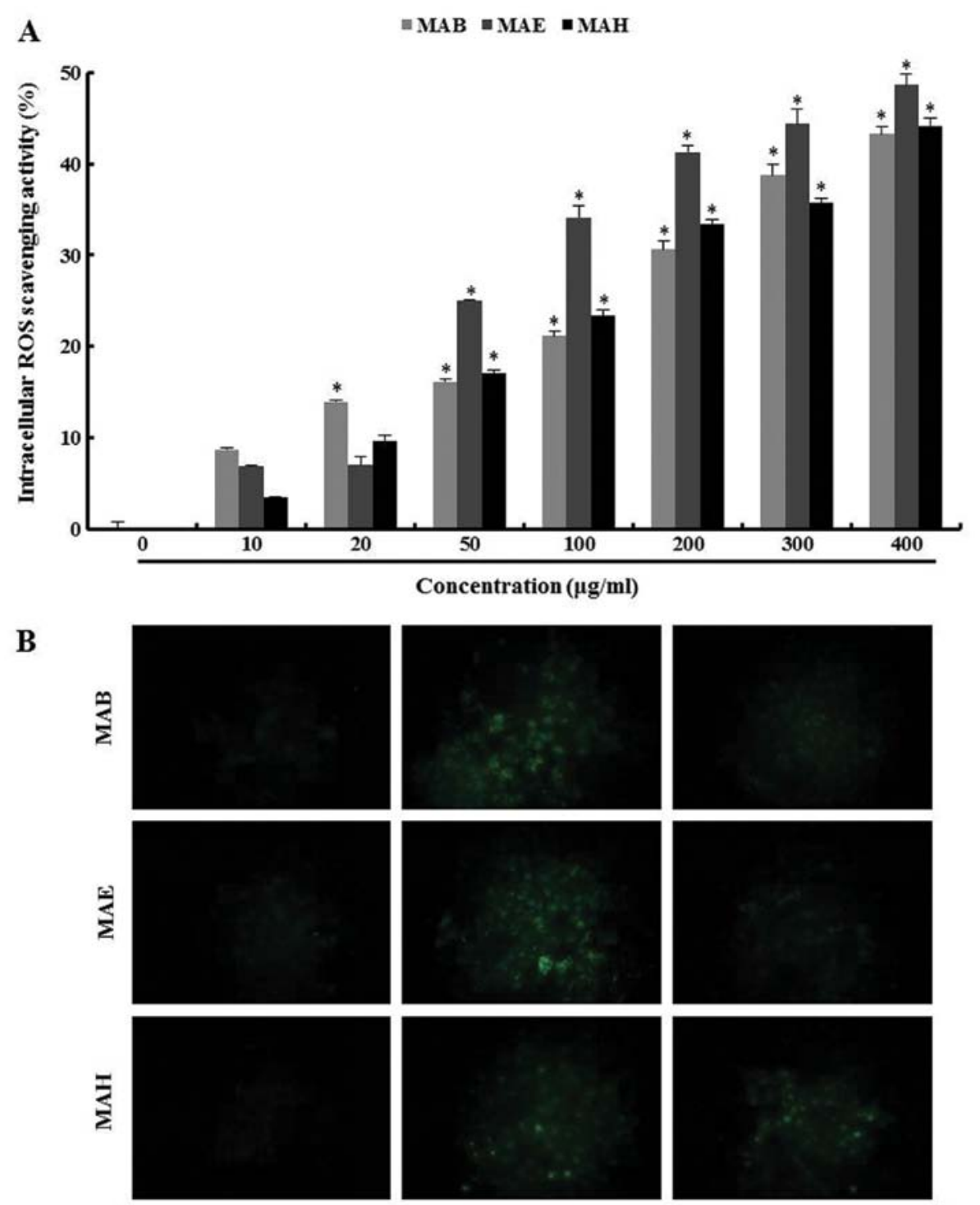

Control

$\mathrm{H}_{2} \mathrm{O}_{2}$

$\mathrm{H}_{2} \mathrm{O}_{2}+100 \mu \mathrm{g} / \mathrm{ml}$

Figure 5. Intracellular reactive oxygen species (ROS) scavenging activity of fractionated extracts in oxidative stress-damaged mouse insulin-producing pancreatic $\beta$-cells (MIN6N cells). MIN6N $\beta$-cells were treated with various concentrations of fractionated extracts $(10-400 \mu \mathrm{g} / \mathrm{ml})$ for $20 \mathrm{~h}$ and $0.7 \mathrm{mM} \mathrm{H} \mathrm{O}_{2}$ was added for $4 \mathrm{~h}$. (A) The intracellular ROS scavenging activity was measured by the DCF-DA method. Data represent the means \pm SE of 3 independent experiments. " $\mathrm{p}<0.05$, significant difference compared with the $\mathrm{H}_{2} \mathrm{O}_{2}$-treated group, as shown by the Student's t-test. (B) Representative fluorescence images illustrate the increase in green fluorescence intensity of DCF produced by ROS in the $\mathrm{H}_{2} \mathrm{O}_{2}$-treated cells as compared with the control or samples co-treated with fractionated extracts. Magnification, x400. MAB, ethyl-acetate extract; MAB, n-butanol extract; MAH, water extract.

peroxidation products, as previously described (28). As shown in Fig. 6, the cells exposed to $\mathrm{H}_{2} \mathrm{O}_{2}$ showed an increase in lipid peroxidation as indicated by the generation of TBARS, whereas, the fractionated extracts inhibited lipid peroxidation. The inhibitory effect of $100 \mu \mathrm{g} / \mathrm{ml} \mathrm{MAB}, \mathrm{MAE}$ and $\mathrm{MAH}$ was 22,29 and $22 \%$, respectively compared with the cells treated only with $\mathrm{H}_{2} \mathrm{O}_{2}$. These results indicate that the ability of the fractionated extracts to block on $\mathrm{H}_{2} \mathrm{O}_{2}$-induced TBARS formation may be due to their intracellular ROS scavenging activity.

Effect of fractionated mulberry extracts on DNA fragmentation in MIN6N $\beta$-cells. In order to confirm the DNA fragmentation induced by $\mathrm{H}_{2} \mathrm{O}_{2}$ in MIN6N $\beta$-cells, we stained their DNA with Hoechst 33342 . The microscopic images in presented Fig. 7 illustrate that treatment the of the cells with
$\mathrm{H}_{2} \mathrm{O}_{2}$ induced DNA fragmentation, a characteristic feature of apoptosis. However, pre-treatment with $100 \mu \mathrm{g} / \mathrm{ml}$ of each fractionated extract decreased the level of DNA fragmentation when compared with the cells treated with $\mathrm{H}_{2} \mathrm{O}_{2}$ alone. These results confirmed that MAB, MAE and MAH inhibited oxidative stress-induced DNA fragmentation in MIN6N $\beta$-cells.

\section{Discussion}

ROS production contributes to metabolic disorders that accompany diabetes (29). Although the body has many natural defense systems to guard against the deleterious effects of ROS, a combination of aging and lifestyle choices can exacerbate their effects. Therefore, preventing the formation of ROS or scavenging intracellular ROS may be a useful treatment for several metabolic disorders. 

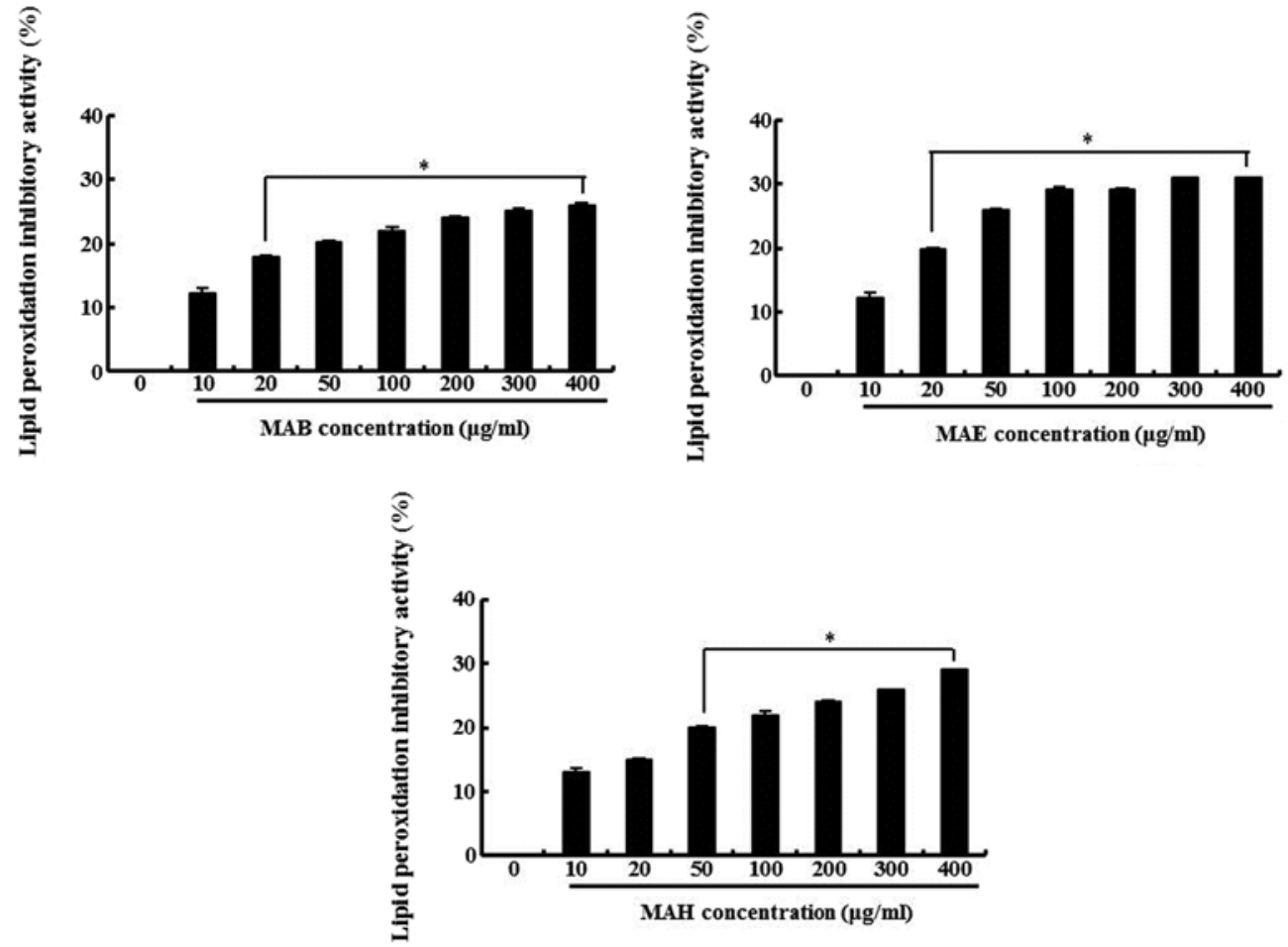

Figure 6. Inhibitory activity of fractionated extracts on lipid peroxidation in oxidative stress-damaged mouse insulin-producing pancreatic $\beta$-cells (MIN6N cells). Confluent cells were incubated with various concentrations $(10-400 \mu \mathrm{g} / \mathrm{ml})$ of fractionated extracts for $20 \mathrm{~h}$ prior to exposure $0.7 \mathrm{mM} \mathrm{H}_{2} \mathrm{O}_{2}$ for $4 \mathrm{~h}$. Lipid peroxidation was assayed by measuring the amount of TBARS formation. Data represent the means \pm SE of 3 independent experiments. "p $<0.05$, significant difference compared with the $\mathrm{H}_{2} \mathrm{O}_{2}$-treated group, as shown by the Student's t-test.MAB, ethyl-acetate extract; MAB, n-butanol extract; MAH, water extract.
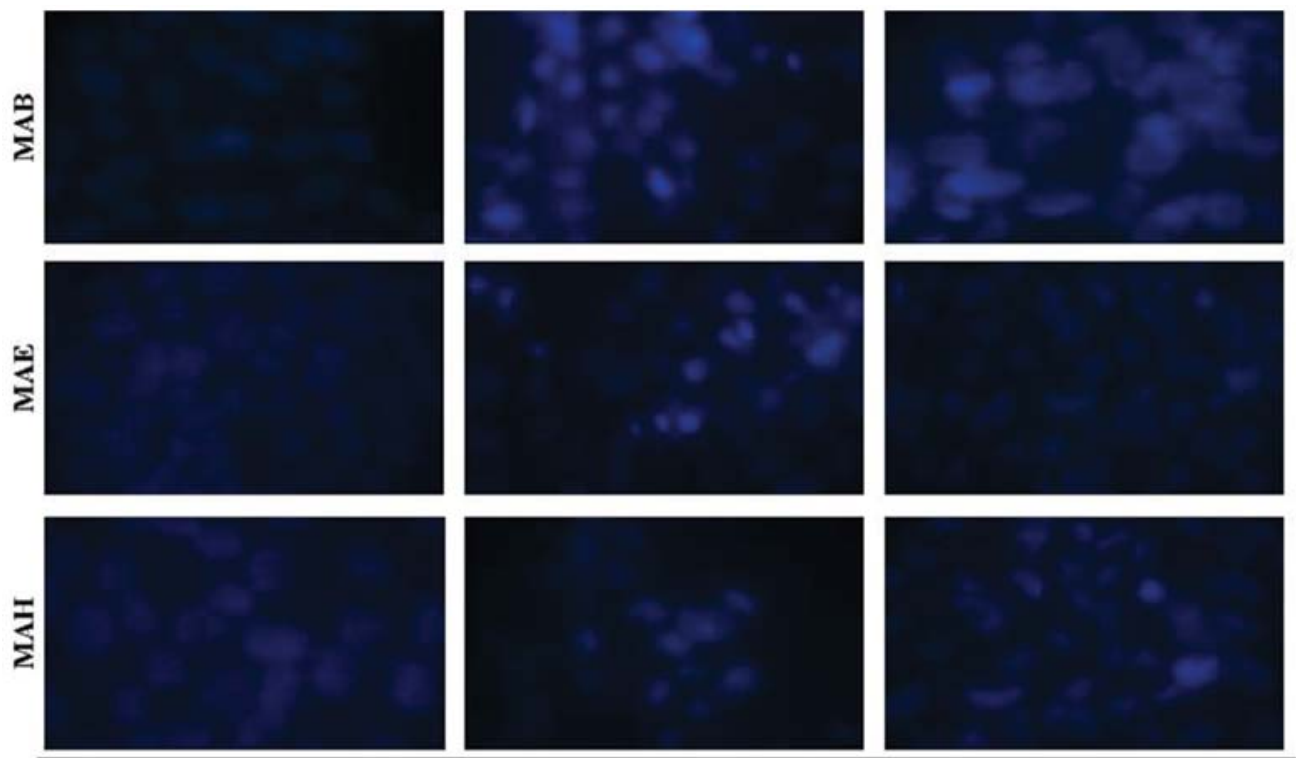

Control

$\mathrm{H}_{2} \mathrm{O}_{2}$

$\mathrm{H}_{2} \mathrm{O}_{2}+100 \mu \mathrm{g} / \mathrm{ml}$

Figure 7. Fluorescence assay of Hoechst 33342 staining. Mouse insulin-producing pancreatic $\beta$-cells (MIN6N cells) were pre-incubated with fractionated extracts for $20 \mathrm{~h}$ and then $0.7 \mathrm{mM} \mathrm{H}_{2} \mathrm{O}_{2}$ was added to the culture medium for $4 \mathrm{~h}$, except for the control group. MIN6N $\beta$-cells were stained with Hoechst 33342 staining solution and visualized using a fluorescence microscope. Magnification, $\mathrm{x} 400$.

In this regard, there is an increasing demand for alternative, safe and low-cost materials/substances with antioxidant properties isolated from natural sources. Some medicinal plants, including Vaccinium spp. and Rubus coreanus, both produce red pigments that are composed of anthocyanin derivatives and polyphenols, which are compounds with antioxidant activity (30-34).
Although $M$. alba is mainly used as a food supply to raise silkworms, its leaves and branches have been used in medicine to treat fever, liver injury and diabetes (35-38). However, the plant also produces compounds with potential antioxidant properties, and in this study, to our knowledge, we demonstrate for the first time that this can be exploited for protection against oxidative stress-induced death of pancreatic cells. 
Specifically, we demonstrated that fractionated mulberry extracts (MAB, MAE and MAH) decreased intracellular DPPH radicals in $\mathrm{H}_{2} \mathrm{O}_{2}$-treated MIN6N $\beta$-cells and that treament with all these extracts effectively attenuated $\mathrm{H}_{2} \mathrm{O}_{2}$-induced $\beta$-cell death. The extracts also reduced $\mathrm{H}_{2} \mathrm{O}_{2}$-induced intracellular ROS and blocked $\mathrm{H}_{2} \mathrm{O}_{2}$-induced cell death by inhibiting lipid peroxidation and DNA fragmentation.

In conclusion, we demonstrate that mulberry extracts protect pancreatic $\beta$-cells against oxidate stress induced by $\mathrm{H}_{2} \mathrm{O}_{2}$ by limiting ROS production, which suggests that such extracts may prove useful in the treatment of diabetes. Finally, we suggest that additional studies are required to further define the mechanisms by which mulberry extracts attenuate oxidative stress and exert anti-diabetic effects in pancreatic $\beta$-cells.

\section{Acknowledgements}

This study was supported by the High Value-added Food Technology Development Program, Ministry of Agriculture, Food and Rural Affairs, Republic of Korea.

\section{References}

1. Blois MS: Free Radicals in Biological Systems. Science 132: 306-307, 1960.

2. Diplock AT, Charleux JL, Crozier-Willi G, et al: Functional food science and defence against reactive oxidative species. Br J Nutr 80 (Suppl 1): S77-S112, 1998.

3. Dalton TP, Shertzer HG and Puga A: Regulation of gene expression by reactive oxygen. Annu Rev Pharmacol Toxicol 39: 67-101, 1999.

4. Blumberg J: Use of biomarkers of oxidative stress in research studies. J Nutr 134: 3188S-3189S, 2004.

5. Lizard G, Fournel S, Genestier L, et al: Kinetics of plasma membrane and mitochondrial alterations in cells undergoing apoptosis. Cytometry 21: 275-283, 1995.

6. Lee JH, Lee JS, Kim YR, et al: Hispidin isolated from Phellinus linteus protects against hydrogen peroxide-induced oxidative stress in pancreatic MIN6N $\beta$-cells. J Med Food 14: 1431-1438, 2011.

7. Maritim AC, Sanders RA and Watkins JB III: Diabetes, oxidative stress, and antioxidants: a review. J Biochem Mol Toxicol 17: 24-38, 2003.

8. Zhong J, Rao X, Xu JF, Yang $\mathrm{P}$ and Wang CY: The role of endoplasmic reticulum stress in autoimmune-mediated beta-cell destruction in type 1 diabetes. Exp Diabetes Res 2012: 238980, 2012.

9. Bach JF: Insulin-dependent diabetes mellitus as an autoimmune disease. Endocr Rev 15: 516-542, 1994.

10. Matsuoka T, Kajimoto Y, Watada H, et al: Glycation-dependent, reactive oxygen species-mediated suppression of the insulin gene promoter activity in HIT cells. J Clin Invest 99: 144-150, 1997.

11. Allen DA, Yaqoob MM and Harwood SM: Mechanisms of high glucose-induced apoptosis and its relationship to diabetic complications. J Nutr Biochem 16: 705-713, 2005.

12. Davis KL, Tangirala M, Meyers JL and Wei W: Real-world comparative outcomes of US type 2 diabetes patients initiating analog basal insulin therapy. Curr Med Res Opin 9: 1083-1091, 2013.

13. Rolo AP and Palmeira CM: Diabetes and mitochondrial function: role of hyperglycemia and oxidative stress. Toxicol Appl Pharmacol 212: 167-178, 2006.

14. Giugliano D, Ceriello A and Paolisso G: Oxidative stress and diabetic vascular complications. Diabetes Care 19: 257-267, 1996.

15. Samyshkin Y, Guillermin AL, Best JH, Brunell SC and Lloyd A: Long-term cost-utility analysis of exenatide once weekly versus insulin glargine for the treatment of type 2 diabetes patients in the US. J Med Econ 15 (Suppl 2): S6-S13, 2012.

16. Koster I, Schubert I and Huppertz E: Follow up of the CoDiM-Study: Cost of diabetes mellitus 2000-2009. Dtsch Med Wochenschr 137: 1013-1016, 2012 (In German).

17. Riblett B: Diabetes mellitus: the undiscussed side effect: sexual dysfunction. RN (For Managers) 46: 40-41, 1983.
18. Pan G and Lou C: Isolation of an 1-aminocyclopropane-1-carboxylate oxidase gene from mulberry (Morus alba L.) and analysis of the function of this gene in plant development and stresses response. J Plant Physiol 165: 1204-1213, 2008.

19. Kim GN, Kwon YI and Jang HD: Mulberry leaf extract reduces postprandial hyperglycemia with few side effects by inhibiting a-glucosidase in normal rats. J Med Food 14: 712-717, 2011.

20. Kwon HJ, Chung JY, Kim JY and Kwon O: Comparison of 1-deoxynojirimycin and aqueous mulberry leaf extract with emphasis on postprandial hypoglycemic effects: in vivo and in vitro studies. J Agric Food Chem 59: 3014-3019, 2011.

21. Zheng ZP, Cheng KW, Zhu Q, Wang XC, Lin ZX and Wang M: Tyrosinase inhibitory constituents from the roots of Morus nigra: a structure-activity relationship study. J Agric Food Chem 58: 5368-5373, 2010.

22. Jin YS, Lee MJ, Han W, Heo SI, Sohn SI and Wang MH: Antioxidant effects and hepatoprotective activity of 2,5-dihydroxy-4,3'-di(beta-d-glucopyranosyloxy)-trans-stilbene from Morus bombycis Koidzumi roots on CCl4-induced liver damage. Free Radic Res 40: 986-992, 2006.

23. Jang JS, Lee JS, Lee JH, et al: Hispidin produced from Phellinus linteus protects pancreatic beta-cells from damage by hydrogen peroxide. Arch Pharm Res 33: 853-861, 2010.

24. Ohkawa H, Ohishi $\mathrm{N}$ and Yagi K: Assay for lipid peroxides in animal tissues by thiobarbituric acid reaction. Anal Biochem 95: 351-358, 1979.

25. Kang KA, Kim JS, Zhang R, et al: KIOM-4 protects against oxidative stress-induced mitochondrial damage in pancreatic $\beta$-cells via its antioxidant effects. Evid Based Complement Alternat Med 2011: 978682, 2011.

26. Gschwind M and Huber G: Apoptotic cell death induced by betaamyloid 1-42 peptide is cell type dependent. J Neurochem 65: 292-300, 1995.

27. Ortega-Camarillo C, Guzman-Grenfell AM, Garcia-Macedo R, et al: Hyperglycemia induces apoptosis and $\mathrm{p} 53$ mobilization to mitochondria in RINm5F cells. Mol Cell Biochem 281: 163-171, 2006.

28. Evans JL, Goldfine ID, Maddux BA and Grodsky GM: Are oxidative stress-activated signaling pathways mediators of insulin resistance and beta-cell dysfunction? Diabetes 52: 1-8, 2003.

29. Zhang R, Kim JS, Kang KA, Piao MJ, Kim KC and Hyun JW: Protective mechanism of KIOM-4 in streptozotocin-induced pancreatic $\beta$-cells damage is involved in the inhibition of endoplasmic reticulum stress. Evid Based Complement Alternat Med 2011: 231938, 2011.

30. Patel KD, Scarano FJ, Kondo M, Hurta RA and Neto CC: Proanthocyanidin-rich extracts from cranberry fruit (Vaccinium macrocarpon Ait.) selectively inhibit the growth of human pathogenic fungi Candida spp. and Cryptococcus neoformans. J Agric Food Chem 59: 12864-12873, 2011.

31. Kim TG, Kang SY, Jung KK, et al: Antiviral activities of extracts isolated from Terminalis chebula Retz., Sanguisorba officinalis L., Rubus coreanus Miq. and Rheum palmatum L. against hepatitis B virus. Phytother Res 15: 718-720, 2001.

32. Ku CS and Mun SP: Antioxidant activities of ethanol extracts from seeds in fresh Bokbunja (Rubus coreanus Miq.) and wine processing waste. Bioresour Technol 99: 4503-4509, 2008.

33. Yang HM, Oh SM, Lim SS, Shin HK, Oh YS and Kim JK: Antiinflammatory activities of Rubus coreanus depend on the degree of fruit ripening. Phytother Res 22: 102-107, 2008.

34. Im SE, Nam TG, Lee H, et al: Anthocyanins in the ripe fruits of Rubus coreanus Miquel and their protective effect on neuronal PC-12 cells. Food Chem 139: 604-610, 2013.

35. Liu JD: Study of the etiology of low-fever among female silkweaving workers: extrinsic allergic alveolitis due to mulberry silk dust exposure. Zhonghua Yu Fang Yi Xue Za Zhi 19: 354-357, 1985 (In Chinese).

36. Yang TP, Lee HJ, Ou TT, Chang YJ and Wang CJ: Mulberry leaf polyphenol extract induced apoptosis involving regulation of adenosine monophosphate-activated protein kinase/fatty acid synthase in a p53-negative hepatocellular carcinoma cell. J Agric Food Chem: Jun 26, 2012 (Epub ahead of print).

37. Kaewkaen P, Tong-Un T, Wattanathorn J, Muchimapura S, Kaewrueng W and Wongcharoenwanakit S: Mulberry fruit extract protects against memory impairment and hippocampal damage in animal model of vascular dementia. Evid Based Complement Alternat Med 2012: 263520, 2012.

38. Kaneto H, Fujii J, Myint T, et al: Reducing sugars trigger oxidative modification and apoptosis in pancreatic beta-cells by provoking oxidative stress through the glycation reaction. Biochem J 320: 855-863, 1996. 